\title{
Improving Fungicide-Based Management of Ray Blight Disease in Tasmanian Pyrethrum Fields
}

Sarah J. Pethybridge and Frank S. Hay, Tasmanian Institute of Agricultural Research (TIAR), University of Tasmania, P.O. Box 3523, Burnie, Tasmania, 7320, Australia; Tim Groom, Botanical Resources Australia Pty. Ltd., 4446 Industrial Drive, Ulverstone, Tasmania, 7315, Australia; and Calum R. Wilson, TIAR, New Town Research Laboratories, 13 St. Johns Ave., New Town, Tasmania, 7008, Australia

\section{ABSTRACT}

Pethybridge, S. J., Hay, F. S., Groom, T., and Wilson, C. R. 2008. Improving fungicide-based management of ray blight disease in Tasmanian pyrethrum fields. Plant Dis. 92:887-895.

Ray blight disease, caused by Phoma ligulicola var. inoxydablis, is a serious threat to the Tasmanian pyrethrum industry. The management of this disease relies upon the strategic application of fungicides in early spring. A range of fungicides were assessed for their efficacy in controlling ray blight disease in Tasmanian pyrethrum fields, and the primary objective of this study was to increase fungicide options available to growers in different resistance groups. Fungicides were assessed under in vitro conditions, within five replicated-plot field trials over three seasons (2004 to 2006) and in single-plot trials over eight fields in 2005. In each of the field trials, regular assessments of disease intensity (defoliation severity and the incidence of stems with ray blight), stem height, and the number of flowers produced on each stem were made using stems as the primary sampling unit. Canopy reflectance at $830 \mathrm{~nm}$ and the Difference Vegetative Index, measured using a handheld multispectral radiometer, also were used to compare fungicide effects on green leaf area. The effect of fungicides on the dry weight of flowers, pyrethrin content within the flowers, flower maturity, and pyrethrin yield were determined. Under in vitro conditions, boscalid reduced both conidial germination and mycelial growth at concentrations of at least $0.16 \mu \mathrm{g} / \mathrm{ml}$. In field trials 1 and 2 (in 2004), the premixed formulation of pyraclostrobin + boscalid (Pristine) increased pyrethrin yield by an average of $79 \%$ compared with nontreated plots over the two locations. Furthermore, in single-plot trials, pyraclostrobin + boscalid increased pyrethrin yield by 134 and $60 \%$ compared with the industry-recommended protocol (single application of azoxystrobin at $150 \mathrm{~g}$ a.i./ha [Amistar WG] and two additional applications of a tank mixture of difenoconazole at $125 \mathrm{~g}$ a.i./ha [Score] and chlorothalonil at 1,008 liters a.i./ha [Bravo 720] at 14- to 21-day intervals) and nontreated plots, respectively. In field trials 3 (in 2005) and 4 and 5 (in 2006), similar yield benefits also were produced by applying pyraclostrobin (Cabrio SC) or boscalid (Filan) alone or in combination with chlorothalonil (Bravo 720) at 1.4 liters of product per hectare, regardless of the rates of pyraclostrobin (250 and $125 \mathrm{~g}$ a.i./ha) and boscalid (500 and $250 \mathrm{~g}$ a.i./ha) used. These data were used to recommend the incorporation of boscalid to improve the fungicide-based management of ray blight disease. This decreases the number of applications of both strobilurin and triazole fungicides which have been used extensively for the management of ray blight and other diseases in Tasmanian pyrethrum fields and are prone to fungicide resistance development.

Additional keywords: disease management, Tanacetum cinerariifolium

Pyrethrum (Tanacetum cinerariifolium (Trevir.) Sch. Bip.) is grown for the production of pyrethrins, which are known for their insecticidal properties. These compounds are present predominantly in glands produced on the achenes of the flower $(7,21)$. The crop is planted by seed in early spring and is harvested for the first time the following midsummer (December and January in the southern hemisphere). Pyrethrum production in Tasmania gives

Corresponding author: S. J. Pethybridge

E-mail: sarah_jp@utas.edu.au

Accepted for publication 28 January 2008.

doi:10.1094/PDIS-92-6-0887

(C) 2008 The American Phytopathological Society a.i./ha (as Amistar WG; Syngenta Australia), to coincide with an average stem height of approximately 5 to $10 \mathrm{~cm}$ (generally in mid- to late August), and two additional applications of a tank mixture of difenoconazole at $125 \mathrm{~g}$ a.i./ha (as Score EC; Syngenta Australia) and chlorothalonil at $1008 \mathrm{~L}$ a.i./ha (as Bravo 720; Syngenta Australia) at 14- to 21-day intervals. Timing the first application in this program with this growth stage has been shown to be critical to its success $(31,37)$. This fungicide program aims to minimize defoliation and keep it below the threshold of approximately $13 \%$ before the disease begins to negatively impact yield through loss of healthy flowers (31).

In 2003 and 2004, research demonstrated the effectiveness of the spring fungicide program in reducing ray blight disease intensity and increasing pyrethrin yield by an average of $79.5 \%$ over 2 years compared with nontreated plots (31). Despite the adoption of best-practice fungicide resistance principles, including minimizing the number of fungicide applications and rotating with products from different resistance classes, there is concern over the effectiveness of these fungicides in the longer term because of the selection of populations with reduced sensitivity to difenoconazole (16). Rapid development of resistance to sterol demethylation inhibitors, such as difenoconazole, has been documented in other pathosystems $(6,10,18,40)$. In addition to the two applications of difenoconazole made in the spring fungicide program, tebuconazole (another member of this class) is applied twice within the summer fungicide program to control white mold flower disease, caused by Sclerotinia sclerotiorum, and Botrytis flower blight, caused by Botrytis cinerea. Fungicide resistance concerns also are especially important for azoxystrobin, which is a member of the strobilurin or quinone outside inhibitors (QoI) group. These fungicides inhibit respiration by binding to the Qo center of the cytochrome $b$, part of the electron transport chain in the inner mitochondrial membrane (10). Rapid development of reduced sensitivity to strobilurins has been observed in a number of plant-pathogenic fungi $(10,15,19)$.

Boscalid has entered the Australian market as Filan (boscalid at $500 \mathrm{~g} / \mathrm{kg}$; Nufarm, Laverton North, Victoria, Austra- 
lia) and in a premixed formulation with pyraclostrobin as Pristine (boscalid at 200 $\mathrm{g} / \mathrm{kg}+$ pyraclostrobin at $100 \mathrm{~g} / \mathrm{kg}$ ). The latter formulation entered the Australian market as an experimental product in 2004 but was not subsequently commercially released. Pyraclostrobin also is a member of the strobilurin group (10). Boscalid is a carboxamide fungicide and is classified as a member of resistance group 7 by the Fungicide Resistance Action Committee (FRAC). It inhibits mitochondrial respiration at the enzyme, succinate ubiquinone reductase, which is present within complex II, in the mitochondrial electron transport chain on the inner mitochondrial membrane (20). Boscalid is effective against a range of diseases, including Sclerotinia stem rot on canola (13), white mold of peanut (39), lettuce drop (23), and Phoma basal rot of romaine lettuce (17). Carboxamide fungicides are regarded as medium risk of resistance development according to FRAC. Despite this, resistance to carboxamide fungicides has been reported in several plant-pathogenic fungi, including Ustilago nuda (C.N. Jensen) Rostr. (22) and Mycosphaerella graminicola (Fuckel) J. Schröt (41). To date, there has been only one report of resistance to boscalid in $\mathrm{Al}$ ternaria alternata (1).

Therefore, these studies were initiated with the objective of identifying alternative fungicides in different resistance groups which may reduce the reliance of the spring fungicide program to control ray blight disease on strobilurin and demethylation inhibitor fungicides. This article describes assessment of new products tested in vitro, in five field trials over 3 years, and in larger scale single-plot tests in eight pyrethrum fields in 1 year.

\section{MATERIALS AND METHODS}

In vitro efficacy of fungicides against P. ligulicola. Six monoconidial P. ligulicola var. inoxydablis isolates were obtained from diseased stems $(16,35)$ in each of six different pyrethrum fields during 2004. Two isolates were obtained from each of the three major production districts (Devonport, Central Coast, and Wynyard). The sensitivity of these isolates to boscalid, pyraclostrobin, and azoxystrobin was tested in mycelial growth and conidial germination assays.

Methods used for the production of monoconidial isolates, long-term storage of these isolates, and in vitro efficacy testing by these assays have been described elsewhere (16). Briefly, in this study, seven different concentrations of each fungicide (0.01, 0.04, 0.16, 0.625, 2.5, 50, and 100 $\mu \mathrm{g} / \mathrm{liter}$ ) and a nonamended control were prepared. Conidial germination assays were conducted using fungicide amendment to water agar (WA), whereas mycelial growth assays used amendment to potato dextrose agar (PDA). For testing of strobilurin fungicide efficacy (azoxy- strobin and pyraclostrobin), salicylhydroxamic acid (SHAM; Sigma-Aldrich, St. Louis) at $100 \mu \mathrm{g} / \mathrm{ml}$ also was added to inhibit alternative oxidase respiration pathways (28). Two control (nonamended) treatments were plates with SHAM and those without. Three replicate plates were prepared for each fungicide concentration and controls, and isolate and tests were performed twice. The technique for production of pycnidia and conidia for conidial germination assays has been described (16). In the current study, the density of conidial suspensions used for inoculating each plate was adjusted to $1 \times 10^{5} \mathrm{co}-$ nidia/ml, and each plate was inoculated with $50 \mu \mathrm{l}$ of suspension, which was spread over the surface with a sterile glass rod. Plates were incubated in the dark for $20 \mathrm{~h}$ at $20^{\circ} \mathrm{C}$. Sixty conidia then were assessed on each plate (total number of conidia per isolate, $n=180$ ) from three microscope fields $(\times 200)$ arbitrarily located on the plate surface (avoiding the edges). A conidium was considered germinated when the germ tube was at least the length of the conidium.

For mycelial growth assays, three replicates of each fungicide concentration, including a nonamended control, were inoculated with a 3-mm-diameter agar plug of each isolate at the center of each plate and incubated in the dark at $20^{\circ} \mathrm{C}$. Plugs were removed from the edge of a colony which also had been growing for 7 days on PDA at $20^{\circ} \mathrm{C}$. Growth along one premarked diameter was measured after 14 days.

The effect of fungicides and interactions between fungicides and isolates on conidial germination $(\%)$ and mycelial growth rate $(\mathrm{mm} /$ day) was assessed by analysis of variance using Genstat 9 (version 1; Adept Scientific Inc., Bethesda, MD).

Efficacy of fungicides under field conditions. Replicated field trials in small plots. Trials 1 and 2 were conducted within commercial pyrethrum fields approaching their first harvest in 2004 at Table Cape $\left(40^{\circ} 57^{\prime} \mathrm{S}, \quad 145^{\circ} 39^{\prime} \mathrm{E}\right)$ and Wynyard $\left(40^{\circ} 58^{\prime} \mathrm{S}, 145^{\circ} 42^{\prime} \mathrm{E}\right)$. Trial 1 consisted of proprietary $\mathrm{cv}$. A, while $\mathrm{cv}$. B was used in trial 2. Absolute disease intensity and the relationships between foliar disease intensity and canopy reflectance have been reported elsewhere (34). Herein, we report the relative efficacy of the fungicides on disease intensity and yield components. The following fungicides were tested: difenoconazole (125 g a.i./ha), chlorothalonil (1,008 $\mathrm{g}$ a.i./ha), azoxystrobin (150 g a.i/ha), kresoxim-methyl (150 g a.i./ha), a premixture of pyraclostrobin $(150 \mathrm{~g}$ a.i./ha) and boscalid (504 g a.i./ha), epoxiconazole (125 g a.i./ha), a premixture of chlorothalonil (750 $\mathrm{g}$ a.i./ha) and pyrimethanil (300 g a.i/ha), and a nontreated control. At Table Cape, fungicides were applied on 24 August, 12 September, and 3 October. At Wynyard, fungi- cides were applied on 27 August and 6 October.

Trial 3 was established in 2005 in a field of cv. A approaching its first harvest at Murdering Gully $\left(40^{\circ} 57^{\prime} \mathrm{S}, 145^{\circ} 43^{\prime} \mathrm{E}\right)$. This trial examined the efficacy of a further range of fungicides on the intensity of ray blight disease during spring and early summer. The fungicides tested were: boscalid (500 g a.i./ha), difenoconazole (125 g a.i./ha), azoxystrobin (150 g a.i./ha), pyraclostrobin ( $250 \mathrm{~g}$ a.i./ha), and two rates of a premixture of pyraclostrobin + boscalid $(150+504 \mathrm{~g}$ a.i./ha and $75+$ $252 \mathrm{~g}$ a.i./ha) (hereafter known as the higher and lower rates, respectively) compared with a nontreated control. Fungicides were applied to plots in trial 3 on 24 August, 14 September, and 4 October.

Trials 4 and 5 were established in 2006 to further assess the efficacy of pyraclostrobin and boscalid on ray blight disease. The fields located at Boat Harbour $\left(40^{\circ} 57^{\prime} \mathrm{S}, 145^{\circ} 41^{\prime} \mathrm{E}\right)$, and Wesley Vale $\left(41^{\circ} 11^{\prime} \mathrm{S}, 146^{\circ} 30^{\prime} \mathrm{E}\right)$, respectively, were planted with $\mathrm{cv}$. A and approaching their first harvest. The treatments were: chlorothalonil (1,008 $\mathrm{g}$ a.i./ha), boscalid (500 g a.i./ha) + chlorothalonil (1,008 g a.i./ha), boscalid $(250 \mathrm{~g}$ a.i./ha $)+$ chlorothalonil (1,008 g a.i./ha), pyraclostrobin (250 g a.i./ha) + chlorothalonil (1,008 g a.i./ha), pyraclostrobin (125 g a.i./ha) + chlorothalonil (1,008 g a.i./ha), pyraclostrobin (250 g a.i./ha) + boscalid (500 g a.i./ha), and a nontreated control. Fungicides were applied to plots in trial 4 on 24 August, 9 September, and 30 September. In trial 5, applications were made on 24 August, 5 September, and 27 September.

In trials 1 through 5 , treatments were replicated five times in a completely randomized design. Fungicides were applied to plots using a motorized Solo 432 sprayer with volumes of 300 liters of water (equivalent) per hectare at $200 \mathrm{kPa}$, using a 1.6-m boom with hollow cone nozzles spaced $40 \mathrm{~cm}$ apart. In trials 1 through 3 , each plot was $6 \mathrm{~m}$ long and $3.2 \mathrm{~m}$ wide $\left(19.2 \mathrm{~m}^{2}\right)$, with $1-\mathrm{m}$ buffers of nontreated pyrethrum. In trials 4 and 5 , plots were 5 $\mathrm{m}$ long and $4 \mathrm{~m}$ wide $\left(20 \mathrm{~m}^{2}\right)$, with $1-\mathrm{m}$ buffers. The entire trial areas also received fungicides for the control of white mold flower disease and Botrytis flower blight from mid-November until harvest (early January). These fungicides were applied by individual growers with a tractormounted spray rig and consisted of two applications of tebuconazole (150.5 g a.i./ha) alternated with one application of carbendazim (375 g a.i./ha).

Single plot field assessments. Based on results of replicated trials 1 and 2 conducted in 2004, the efficacy of pyraclostrobin + boscalid was assessed further in eight pyrethrum fields, all approaching their first harvest in 2005. Fields were selected from all production districts from 
Devonport, Central Coast, and Wynyard. Each field received similar standard production practices, including irrigation, fertilizer, and herbicide applications. Within all fields, an area (10 m long by 24 $\mathrm{m}$ wide) was selected where each grower did not apply fungicides for the control of ray blight disease in spring. A second area (approximately $1 \mathrm{ha}$ ) also was selected for the application of pyraclostrobin at $150 \mathrm{~g}$ a.i./ha + boscalid at $504 \mathrm{~g}$ a.i./ha (as Pristine). The remainder of each field received fungicides from the commercial recommendations described above. Application of the pyraclostrobin + boscalid and commercial recommendations were made on the same day at each location using standard tractor-mounted spray equipment. Three applications were made at 14- to 18day intervals, with the first application coinciding with an average stem height of 5 to $10 \mathrm{~cm}$ (37).

Plant density and visual disease intensity estimation. Plant density (number of plants per square meter) and disease intensity was assessed at all locations prior to the application of fungicides (10 to 20 August in each year). Plant density was assessed by counting the number of plants in four $0.75-\mathrm{m}^{2}$ quadrats in each plot. Assessments of disease intensity prior to fungicide application used an individual leaf as the primary sampling unit. Ten leaves were selected systematically in a diagonal transect across each plot. An average disease severity for each plot then was calculated. Disease severity was assessed by estimating the area of the leaf affected by necrosis and comparing this with disease area diagrams constructed from scanned images of individual, fullsize illustrations of pyrethrum leaves (36). Assessments and estimation skills of the one person assessing severity on leaves were tested and refined as described (37) based on the principles described by Nutter and Esker (27) to maximize precision, accuracy, and reproducibility of severity assessments.

After fungicides had been applied, flowering stems were the primary sampling unit. In trials 1 and 2 , disease intensity assessments were made on 15 October and 18 November. In trial 3, disease intensity was assessed on 12 October and 22 November. Disease intensity was assessed on 17 August, 11 October, 24 October, and 20 November in trial 4 and on 8 August, 24 October, and 20 November in trial 5. In the eight single-plot trials, disease intensity was assessed between 4 to 5 September, 5 to 6 October, and 15 to 17 November.

For all assessments, 20 flowering stems were selected systematically along a single diagonal transect across each plot (trials 1 through 5) or along three linear transects (60 stems/plot in total) for the single-plot trials. The methodology used to assess disease intensity on flowering stems has been described previously (32). In brief, each stem was removed from the base of the plant and stored at $4^{\circ} \mathrm{C}$ until visual assessments were performed in the laboratory within $48 \mathrm{~h}$. Defoliation severity (\%) was defined as the height to defoliation (leaves either completely necrotic or abscised) divided by the total stem length. On each stem, the number of flowers or buds also was counted, and each was noted to be either healthy or diseased. The incidence of stems with ray blight (\%), defined as the number of stems with at least one diseased flower or bud divided by the total number of stems, then was calculated. For all assessments, the average per plot was calculated for statistical analyses.

Radiometric assessment of disease intensity and yield. In trials 1 through 5, canopy reflectance also was used to assess disease intensity following the application of fungicides. Reflectance within the near infrared range $(830 \mathrm{~nm})$ and the difference vegetative index (DVI) $\left\{R_{830}-\right.$ $\left.\left[\left(R_{560}+R_{660}\right)\right] / 2\right\}$ (6) have been demonstrated to give accurate, precise, and reproducible assessments of disease intensity (34) and are strongly related to relative flower yield (33) during this time. Measurements of canopy reflectance have advantages over visual disease intensity assessments, including the ability to account for reductions in green leaf area due to reductions in plant growth caused by disease (12).
Incident and reflected radiation was measured with a handheld, multispectral radiometer (MSR5; CropScan Inc., Rochester, MN) at five narrow-wavelength bands $(485,560,660,830$, and $1,650 \mathrm{~nm})$. In trials 1 and 2, canopy reflectance measurements were taken on 16 October and 20 November. In trial 3, canopy reflectance measurements were taken on the same day as visual assessments, prior to destructive removal of flowering stems (12 October and 22 November). In trials 4 and 5, canopy reflectance was measured 2 days before visual disease intensity assessments in November due to predicted cloud cover and, therefore, insufficient light intensity $\left(<500\right.$ watts $\left./ \mathrm{m}^{2}\right)$. Methods used to assess canopy reflectance in pyrethrum have been reported elsewhere $(33,34)$. All canopy reflectance readings were obtained between 1100 and $1400 \mathrm{~h}$ (Eastern Australian Standard Time) to minimize variation from sun angle (11) and percent reflectance was calculated as a percentage of the voltage value for the reflected radiation divided by the voltage value for the incident radiation at each of the wavelengths. The use of the DVI has been shown to further reduce the variability in reflectance associated with light intensity, sun angle, and dense canopies, such as pyrethrum $(4,5,26,33,34)$. Four readings were taken for each plot at a height of $2 \mathrm{~m}$ in all trials. These then were averaged to provide a single reading for each plot.

Effect of fungicides on yield components. The effect of fungicides on flower yield, pyrethrin content, and total pyrethrin yield was assessed by hand removal of flowers from four quadrats $\left(0.5 \mathrm{~m}^{2}\right)$ in each plot for all trials between 12 and 17 December of each year. This varied between 10 and 17 days before commercial cutting of the entire field. Flower samples were stored at $4^{\circ} \mathrm{C}$ for no more than $24 \mathrm{~h}$ before fresh weights were recorded. Dry weights were determined by removal of a subsample consisting of approximately $20 \%( \pm 2 \%)$ of the entire sample. This sample was dried for $24 \mathrm{~h}$ at $60^{\circ} \mathrm{C}$. Pyrethrin content was assessed in a second 20$\mathrm{g}$ sample that had been dried further at $55^{\circ} \mathrm{C}$ for an additional $36 \mathrm{~h}$. The methods

Table 1. Effect of a range of fungicides on in vitro mycelial growth rate and conidial germination of Phoma ligulicola

\begin{tabular}{|c|c|c|c|c|c|c|}
\hline \multirow[b]{2}{*}{ Fungicide concentration $(\mu \mathrm{g} / \mathrm{ml})$} & \multicolumn{3}{|c|}{ Mycelial growth rate (mm/day) } & \multicolumn{3}{|c|}{ Germination of conidia $(\%)$} \\
\hline & Boscalid & Pyraclostrobin & Azoxystrobin & Boscalid & Pyraclostrobin & Azoxystrobin \\
\hline 100 & $5 \mathrm{~d}$ & $49 \mathrm{~b}$ & $44 \mathrm{~b}$ & $0 \mathrm{c}$ & $8 \mathrm{f}$ & $10 \mathrm{~d}$ \\
\hline 50 & $5 \mathrm{~d}$ & $52 \mathrm{~b}$ & $45 \mathrm{~b}$ & $0 \mathrm{c}$ & $23 \mathrm{e}$ & $20 \mathrm{~d}$ \\
\hline 2.5 & $5 \mathrm{~d}$ & $51 \mathrm{~b}$ & $42 \mathrm{~b}$ & $2 \mathrm{c}$ & $65 \mathrm{~d}$ & $60 \mathrm{c}$ \\
\hline 0.625 & $5 \mathrm{~d}$ & $50 \mathrm{~b}$ & $46 \mathrm{~b}$ & $5 \mathrm{c}$ & $78 \mathrm{c}$ & $76 \mathrm{~b}$ \\
\hline 0.16 & $8 \mathrm{~d}$ & $52 \mathrm{~b}$ & $46 \mathrm{~b}$ & $75 \mathrm{~b}$ & $88 \mathrm{a}$ & $85 \mathrm{ab}$ \\
\hline 0.04 & $38 \mathrm{c}$ & $60 \mathrm{a}$ & $56 \mathrm{a}$ & $90 \mathrm{a}$ & $92 \mathrm{a}$ & $90 \mathrm{a}$ \\
\hline 0.01 & $52 \mathrm{~b}$ & $62 \mathrm{a}$ & $58 \mathrm{a}$ & $92 \mathrm{a}$ & $95 \mathrm{a}$ & 96 a \\
\hline $0(+ \text { SHAM })^{\mathrm{z}}$ & $\ldots$ & $62 \mathrm{a}$ & $61 \mathrm{a}$ & $\ldots$ & $98 \mathrm{a}$ & $95 \mathrm{a}$ \\
\hline 0 (unamended) & $65 \mathrm{a}$ & $64 \mathrm{a}$ & $62 \mathrm{a}$ & $95 \mathrm{a}$ & $98 \mathrm{a}$ & $97 \mathrm{a}$ \\
\hline $\operatorname{LSD}(P<0.001)$ & 3 & 7 & 8 & 11 & 8 & 10 \\
\hline
\end{tabular}

y Data presented is across six isolates and averaged over two repeats of the experiment; within columns, means followed by the same letter are not significantly different at $P=0.05 ;$ LSD $=$ least significant difference.

${ }^{\mathrm{z}}$ Effect of salicylhydroxamic acid (SHAM) on conidial germination was not significant $(P=0.877)$. 
used to analyze pyrethrin content have been reported elsewhere $(31,37)$ and were based on the normal-phase highperformance liquid chromatography procedure as described by McEldowney and Menary (24), using comparisons to a validated reference standard of pyrethrins extracted from plant material (14).

Flower maturity. The effect of fungicides on flower maturity was assessed on a 100 -g flower sample from each plot in all trials. Individual flowers were sorted into each of the eight stages representing pyrethrum flower maturity (37). The number of flowers within each flower stage category was counted and multiplied by a scaling factor to achieve a weighted mean average assessment of flower maturity. The incidence of flowers with ray blight within each sample was counted and expressed as a percentage.

Data analysis. The effect of fungicides on disease intensity, stem height, the number of flowers produced on each stem, and yield components (dry weight of flowers [g], pyrethrin content [\%], pyrethrin yield $[\mathrm{kg} / \mathrm{ha}])$, flower maturity, and the incidence of flowers with ray blight $(\%)$ was assessed by analysis of variance (Genstat 9; version 1, Adept Scientific Inc.). Means were separated with Fisher's protected least significant difference test $(P=0.05)$.

\section{RESULTS}

In vitro efficacy of fungicides against P. ligulicola var. inoxydablis. Amendment with boscalid, pyraclostrobin, and azoxystrobin significantly reduced both mycelial growth and conidial germination of $P$. ligulicola var. inoxydablis (Table $1 ; P<$ 0.001 ). No significant interactions between fungicide and isolate were identified $(P=0.722)$. The concentrations at which each fungicide resulted in a significant reduction compared with the nonamended controls differed with assay. Amendment with boscalid significantly reduced mycelial growth compared with nonamended controls at the lowest concentration tested $(0.01 \mu \mathrm{g}$ a.i. $/ \mathrm{ml})$. Concentrations above $0.16 \mu \mathrm{g}$ a.i./ml resulted in complete inhibition of mycelial growth. Boscalid also was effective at reducing conidial germination, with concentrations of $0.625 \mu \mathrm{g}$ a.i./ml resulting in $5 \%$ or less of conidia germinating and with no germination at $50 \mu \mathrm{g}$ a.i. $/ \mathrm{ml}$. Amendment with either of the strobilurin fungicides (pyraclostrobin and azoxystrobin) resulted in significant reductions in mycelial growth, compared with nonamended controls, from concentrations of $0.16 \mu \mathrm{g}$ a.i./ml or higher. At the highest concentration tested, colony diameters were reduced by approximately 13 to $15 \mathrm{~mm}$ compared with nonamended control plates. As expected, pyraclostrobin and azoxystrobin were highly effective in reducing conidial germination at concentrations greater than $2.5 \mu \mathrm{g}$ a.i./ml, but none of these concentrations resulted in complete inhibition (Table 1).
Efficacy of fungicides under field conditions (Tables 2-6). Replicated field trials in small plots. Trials 1 and 2. In trials 1 and 2, on both assessment dates all fungicide treatments had taller stems and reduced defoliation severity compared with nontreated plots (Tables 2 and 3). In trial 1, plots receiving pyraclostrobin + boscalid had significantly taller stems and lower disease severity than all other treatments, with $88 \%$ taller stems and $88 \%$ lower defoliation severity compared with nontreated plots on 15 October. On 15 October, flowers per stem were increased by 250 and $160 \%$ from application of pyraclostrobin + boscalid and azoxystrobin, respectively, compared with nontreated plots (Table 2). On 18 November, plots receiving all fungicides except epoxiconazole had more flowers per stem than nontreated plots, ranging from 84 to $216 \%$ in plots receiving chlorothalonil and pyraclostrobin + boscalid, respectively, and less of these stems had diseased flowers. On both assessments, canopy reflectance at $830 \mathrm{~nm}$ and the DVI in plots receiving fungicides was from 9 to $73 \%$ higher compared with nontreated plots (Table 2).

In trial 2, all fungicides on 15 October and all fungicides with the exception of epoxiconazole on 18 November had taller stems and less defoliation than in nontreated plots (Table 3 ). On 15 October, plots receiving pyraclostrobin + boscalid had taller stems than all other fungicides,

Table 2. Effect of fungicides on visually and remotely assessed disease intensity in field trial $1^{\mathrm{z}}$

\begin{tabular}{|c|c|c|c|c|c|c|c|c|c|c|c|c|}
\hline \multirow[b]{2}{*}{ Treatments } & \multicolumn{2}{|c|}{$\begin{array}{l}\text { Stem height } \\
(\mathrm{cm})\end{array}$} & \multicolumn{2}{|c|}{$\begin{array}{c}\text { Defoliation } \\
\text { severity }(\%)\end{array}$} & \multicolumn{2}{|c|}{$\begin{array}{l}\text { Flowers } \\
\text { per stem }\end{array}$} & \multicolumn{2}{|c|}{$\begin{array}{c}\text { Stems with } \\
\text { ray blight }(\%)\end{array}$} & \multicolumn{2}{|c|}{$\mathbf{R}_{\mathbf{8 3 0}}$} & \multicolumn{2}{|c|}{ DVI } \\
\hline & 15 Oct & 18 Nov & 15 Oct & 18 Nov & 15 Oct & $18 \mathrm{Nov}$ & 15 Oct & $18 \mathrm{Nov}$ & 16 Oct & 20 Nov & 16 Oct & 20 Nov \\
\hline Azoxystrobin & $41.9 \mathrm{~b}$ & $67.8 \mathrm{~b}$ & $26.7 \mathrm{~d}$ & $33.6 \mathrm{~d}$ & $3.9 \mathrm{~b}$ & $9.3 \mathrm{~b}$ & $6 \mathrm{c}$ & $0 \mathrm{c}$ & $59.8 \mathrm{~b}$ & $37.8 \mathrm{bc}$ & $53.2 \mathrm{~b}$ & $27.7 \mathrm{bc}$ \\
\hline Pyraclostrobin + boscalid & $53.9 \mathrm{a}$ & $75.9 \mathrm{a}$ & $9 \mathrm{e}$ & $5.4 \mathrm{e}$ & $5.2 \mathrm{a}$ & $13.6 \mathrm{a}$ & $0 \mathrm{c}$ & $0 \mathrm{c}$ & $67.8 \mathrm{a}$ & $44.8 \mathrm{a}$ & $61.1 \mathrm{a}$ & $34.2 \mathrm{a}$ \\
\hline Kresoxim-methyl & $37.9 \mathrm{bc}$ & $66.1 \mathrm{bc}$ & $47.6 \mathrm{bc}$ & $37 \mathrm{~cd}$ & $2.6 \mathrm{c}$ & $8.3 \mathrm{~b}$ & $36 \mathrm{a}$ & $18 \mathrm{bc}$ & $54.0 \mathrm{~d}$ & $36.2 \mathrm{bcd}$ & $47.4 \mathrm{de}$ & $24.8 \mathrm{de}$ \\
\hline Chlorothalonil & $35 \mathrm{c}$ & $60 \mathrm{~cd}$ & $51.4 \mathrm{~b}$ & $47.1 \mathrm{c}$ & $2 \mathrm{c}$ & $7.9 \mathrm{~b}$ & $34 \mathrm{ab}$ & $30 \mathrm{~b}$ & $53.9 \mathrm{~d}$ & $33.5 \mathrm{de}$ & $47.2 \mathrm{e}$ & 22.5 ef \\
\hline Epoxiconazole & $35.1 \mathrm{c}$ & $54.6 \mathrm{~d}$ & $49.1 \mathrm{~b}$ & $60.8 \mathrm{~b}$ & $2.6 \mathrm{c}$ & $5.5 \mathrm{c}$ & $42 \mathrm{a}$ & $86 \mathrm{a}$ & $58.2 \mathrm{bc}$ & 35.5 cde & $51.5 \mathrm{c}$ & $25.5 \mathrm{~cd}$ \\
\hline Pyrimethanil + chlorothalonil & $37.9 \mathrm{bc}$ & $64.5 \mathrm{bc}$ & $38.7 \mathrm{c}$ & $42 \mathrm{~cd}$ & $2.2 \mathrm{c}$ & $8.8 \mathrm{~b}$ & $22 \mathrm{~b}$ & $16 \mathrm{bc}$ & $57.8 \mathrm{bc}$ & $37.9 \mathrm{bc}$ & $51.3 \mathrm{c}$ & $27.6 \mathrm{bc}$ \\
\hline Nontreated & $28.6 \mathrm{~d}$ & $45.2 \mathrm{e}$ & $77.3 \mathrm{a}$ & $80.1 \mathrm{a}$ & $1.5 \mathrm{c}$ & $4.3 \mathrm{c}$ & $50.7 \mathrm{a}$ & $64.3 \mathrm{a}$ & $49.3 \mathrm{e}$ & $29.5 \mathrm{f}$ & $42.6 \mathrm{f}$ & $19.8 \mathrm{~g}$ \\
\hline $\operatorname{LSD}(P<0.001)$ & 5.2 & 6.3 & 10.2 & 11.2 & 1.1 & 1.5 & 14.5 & 25.2 & 3.5 & 3.1 & 3.4 & $2.5^{\circ}$ \\
\hline $\mathrm{CV}(\%)$ & 18.1 & 17.5 & 23.1 & 19.5 & 5.6 & 7.8 & 14.6 & 16.2 & 6.0 & 8.5 & 6.6 & 10.1 \\
\hline
\end{tabular}

z Within columns, means followed by the same letter are not significantly different at $P=0.05$; LSD $=$ least significant difference; CV ( $\%$ ) $=$ coefficient of variation; $R_{830}=$ reflectance at $830 \mathrm{~nm}$; and DVI = difference vegetative index. Higher values of $R_{830}$ and the DVI indicate less foliar disease.

Table 3. Effect of fungicides on visually and remotely assessed disease intensity in field trial $2^{z}$

\begin{tabular}{|c|c|c|c|c|c|c|c|c|c|c|c|c|}
\hline \multirow[b]{2}{*}{ Treatments } & \multicolumn{2}{|c|}{$\begin{array}{l}\text { Stem height } \\
(\mathrm{cm})\end{array}$} & \multicolumn{2}{|c|}{$\begin{array}{c}\text { Defoliation } \\
\text { severity }(\%)\end{array}$} & \multicolumn{2}{|c|}{$\begin{array}{l}\text { Flowers } \\
\text { per stem }\end{array}$} & \multicolumn{2}{|c|}{$\begin{array}{c}\text { Stems with } \\
\text { ray blight }(\%)\end{array}$} & \multicolumn{2}{|c|}{$\mathbf{R}_{\mathbf{8 3 0}}$} & \multicolumn{2}{|c|}{ DVI } \\
\hline & 15 Oct & 18 Nov & 15 Oct & 18 Nov & 15 Oct & 18 Nov & 15 Oct & 18 Nov & 16 Oct & $20 \mathrm{Nov}$ & 16 Oct & $20 \mathrm{Nov}$ \\
\hline Azoxystrobin & $44.2 \mathrm{~b}$ & $75.8 \mathrm{a}$ & $6.5 \mathrm{e}$ & $35.1 \mathrm{bc}$ & $3.9 \mathrm{~b}$ & $4.8 \mathrm{bc}$ & $0 \mathrm{~d}$ & $0 \mathrm{~b}$ & $73.3 \mathrm{a}$ & $48 \mathrm{~b}$ & $66.5 \mathrm{a}$ & $41.4 \mathrm{ab}$ \\
\hline Pyraclostrobin + boscalid & $50.1 \mathrm{a}$ & $79.4 \mathrm{a}$ & $3.3 \mathrm{e}$ & $23.8 \mathrm{c}$ & $5.8 \mathrm{a}$ & $6.8 \mathrm{a}$ & $0 \mathrm{~d}$ & $0 \mathrm{~b}$ & $74.5 \mathrm{a}$ & $50.2 \mathrm{a}$ & $67.7 \mathrm{a}$ & $43.3 \mathrm{a}$ \\
\hline Kresoxim-methyl & $40.8 \mathrm{~b}$ & $74.6 \mathrm{a}$ & $34.3 \mathrm{~cd}$ & $30.9 \mathrm{bc}$ & $2.2 \mathrm{c}$ & $4.5 \mathrm{bc}$ & $32 \mathrm{ab}$ & $0 \mathrm{~b}$ & $64.1 \mathrm{~cd}$ & $44.5 \mathrm{~cd}$ & $57.4 \mathrm{~cd}$ & $37.9 \mathrm{~cd}$ \\
\hline Chlorothalonil & $33.9 \mathrm{~d}$ & $72.7 \mathrm{ab}$ & $47.9 \mathrm{~b}$ & $30.1 \mathrm{c}$ & $2.1 \mathrm{c}$ & $6 a b$ & $22 \mathrm{bc}$ & $4 \mathrm{~b}$ & $66.1 \mathrm{bc}$ & $43.7 \mathrm{~cd}$ & $59.3 \mathrm{bc}$ & $36.7 \mathrm{~cd}$ \\
\hline Epoxiconazole & $33.2 \mathrm{~d}$ & $67.3 \mathrm{bc}$ & $55.6 \mathrm{~b}$ & $44 \mathrm{ab}$ & $2.2 \mathrm{c}$ & $3.7 \mathrm{c}$ & $28 \mathrm{ab}$ & $6 a b$ & $68.7 \mathrm{~b}$ & $47.8 \mathrm{~b}$ & $61.9 \mathrm{~b}$ & $40.9 \mathrm{~b}$ \\
\hline Pyrimethanil + chlorothalonil & $38.5 \mathrm{c}$ & $75.7 \mathrm{a}$ & $30.3 \mathrm{~d}$ & $33.9 \mathrm{bc}$ & $2.5 \mathrm{c}$ & $5.3 \mathrm{abc}$ & $16 \mathrm{c}$ & $4 \mathrm{~b}$ & $66.9 \mathrm{bc}$ & $45.1 \mathrm{c}$ & $60.0 \mathrm{bc}$ & $38.4 \mathrm{c}$ \\
\hline Nontreated & $23.4 \mathrm{e}$ & $63.3 \mathrm{c}$ & $70.1 \mathrm{a}$ & $50.3 \mathrm{a}$ & $2 \mathrm{c}$ & $4.1 \mathrm{c}$ & $39.3 \mathrm{a}$ & $18.6 \mathrm{a}$ & $61.4 \mathrm{~d}$ & $42.9 \mathrm{~d}$ & $54.7 \mathrm{~d}$ & $36.1 \mathrm{~d}$ \\
\hline $\operatorname{LSD}(P \leq 0.041)$ & 4.5 & 7.2 & 10.2 & 13.6 & 1.1 & 1.8 & 11.3 & 13.8 & 3.4 & 2.2 & 3.2 & 2.2 \\
\hline $\mathrm{CV}(\%)$ & 16.9 & 18.1 & 25.4 & 21.1 & 6.4 & 5.4 & 15.4 & 15.8 & 10.8 & 11.2 & 12.7 & 15.6 \\
\hline
\end{tabular}

${ }^{\mathrm{z}}$ Within columns, means followed by the same letter are not significantly different at $P=0.05$; LSD $=$ least significant difference; CV ( $\%$ ) $=$ coefficient of variation; $R_{830}=$ reflectance at $830 \mathrm{~nm}$; and DVI = difference vegetative index. Higher values of $\mathrm{R}_{830}$ and the DVI indicate less foliar disease. 
with stems $114 \%$ taller than in nontreated plots. Plots receiving pyraclostrobin + boscalid and azoxystrobin had less defoliation than all other fungicides on 15 October, and 91 and $95 \%$ less than the nontreated plots, respectively. On 15 October, the flowers per stem was increased by 132 and $56 \%$ in plots receiving pyraclostrobin + boscalid and azoxystrobin, respectively, compared with nontreated plots. On 18 November, $65 \%$ more flowers were produced per stem from the application of pyraclostrobin + boscalid compared with nontreated plots. Canopy reflectance at $830 \mathrm{~nm}$ and DVI, in plots receiving fungicides, except kresoximmethyl, ranged between 8 and 24\% higher than nontreated plots on 15 October. On 20 November, canopy reflectance in plots receiving fungicides, except chlorothalonil and kresoxim-methyl, ranged between 5 and $24 \%$ higher compared with nontreated plots (Table 3).

In both trials, no additional reductions in disease intensity or increase in stem height, number of flowers per stem, and canopy reflectance were found from the addition of pyrimethanil compared with chlorothalonil alone. Similarly, there was some suggestion that kresoxim-methyl was less efficacious than azoxystrobin, with the former having higher disease intensity (defoliation severity and incidence of stems with ray blight) and lower canopy reflectance.

Flower maturity was similar among fungicides in both trials (trial $1, P=0.06$; trial

Table 4. Effect of fungicides on visually and remotely assessed disease intensity in field trial $3^{\mathrm{y}}$

\begin{tabular}{|c|c|c|c|c|c|c|c|c|c|c|c|c|}
\hline \multirow[b]{2}{*}{ Treatments $^{\mathrm{z}}$} & \multicolumn{2}{|c|}{$\begin{array}{l}\text { Stem height } \\
(\mathrm{cm})\end{array}$} & \multicolumn{2}{|c|}{$\begin{array}{c}\text { Defoliation } \\
\text { severity }(\%)\end{array}$} & \multicolumn{2}{|c|}{$\begin{array}{l}\text { Flowers } \\
\text { per stem }\end{array}$} & \multicolumn{2}{|c|}{$\begin{array}{c}\text { Stems with } \\
\text { ray blight }(\%)\end{array}$} & \multicolumn{2}{|c|}{$\mathbf{R}_{\mathbf{8 3 0}}$} & \multicolumn{2}{|c|}{ DVI } \\
\hline & 12 Oct & $22 \mathrm{Nov}$ & 12 Oct & 22 Nov & 12 Oct & $22 \mathrm{Nov}$ & 12 Oct & $22 \mathrm{Nov}$ & 12 Oct & $22 \mathrm{Nov}$ & 12 Oct & 22 Nov \\
\hline Azoxystrobin & $33.3 \mathrm{c}$ & $72.8 \mathrm{c}$ & $15.0 \mathrm{c}$ & $46.6 \mathrm{bc}$ & $1.8 \mathrm{~cd}$ & $4.9 \mathrm{a}$ & $0 \mathrm{c}$ & $12.0 \mathrm{bc}$ & $44.5 \mathrm{~b}$ & $40.0 \mathrm{c}$ & $39.9 \mathrm{~b}$ & $34.6 \mathrm{c}$ \\
\hline Pyraclostrobin & $37.5 \mathrm{ab}$ & $77.8 \mathrm{~b}$ & $11.4 \mathrm{c}$ & $42.3 \mathrm{~cd}$ & $2.3 \mathrm{ab}$ & $4.7 \mathrm{ab}$ & $4.0 \mathrm{c}$ & $8.0 \mathrm{c}$ & $46.2 \mathrm{ab}$ & $42.0 \mathrm{bc}$ & $41.6 \mathrm{ab}$ & $36.5 \mathrm{bc}$ \\
\hline Pyraclostrobin, low & $39.9 \mathrm{a}$ & $80.2 \mathrm{ab}$ & $9.2 \mathrm{c}$ & $41.0 \mathrm{~cd}$ & $2.6 \mathrm{a}$ & $5.0 \mathrm{a}$ & $0 \mathrm{c}$ & $0 \mathrm{c}$ & $47.8 \mathrm{a}$ & $43.4 \mathrm{ab}$ & $43.1 \mathrm{a}$ & $37.8 \mathrm{ab}$ \\
\hline Pyraclostrobin, high & $37.4 \mathrm{ab}$ & $82.4 \mathrm{a}$ & $10.4 \mathrm{c}$ & $36.0 \mathrm{~d}$ & $2.4 \mathrm{a}$ & $5.0 \mathrm{a}$ & $0 \mathrm{c}$ & $0 \mathrm{c}$ & $49.0 \mathrm{a}$ & $43.8 \mathrm{ab}$ & $44.2 \mathrm{a}$ & $38.0 \mathrm{ab}$ \\
\hline Boscalid & $36.8 \mathrm{abc}$ & $77.3 \mathrm{~b}$ & $9.8 \mathrm{c}$ & $40.4 \mathrm{~cd}$ & $2.2 \mathrm{abc}$ & $5.3 \mathrm{a}$ & $0 \mathrm{c}$ & $0 \mathrm{c}$ & $46.8 \mathrm{ab}$ & $44.3 \mathrm{ab}$ & $42.0 \mathrm{ab}$ & $38.6 \mathrm{ab}$ \\
\hline Difenoconazole & $33.9 \mathrm{bc}$ & $65.3 \mathrm{~d}$ & $23.9 \mathrm{~b}$ & $49.8 \mathrm{~b}$ & $1.9 \mathrm{bcd}$ & $3.9 \mathrm{~b}$ & $18.0 \mathrm{~b}$ & $26.0 \mathrm{~b}$ & $41.0 \mathrm{c}$ & $36.8 \mathrm{~d}$ & $36.4 \mathrm{c}$ & $31.1 \mathrm{~d}$ \\
\hline Nontreated & $23.3 \mathrm{~d}$ & $49.4 \mathrm{e}$ & $56.8 \mathrm{a}$ & $76.4 \mathrm{a}$ & $1.7 \mathrm{~d}$ & $4.0 \mathrm{~b}$ & $56.4 \mathrm{a}$ & $60.7 \mathrm{a}$ & $27.4 \mathrm{~d}$ & $23.0 \mathrm{e}$ & $23.2 \mathrm{~d}$ & $18.5 \mathrm{e}$ \\
\hline $\operatorname{LSD}(P \leq 0.013)$ & 3.8 & 3.5 & 8.4 & 6.7 & 0.5 & 0.8 & 11.7 & 14.3 & 2.8 & 2.4 & 2.6 & 2.1 \\
\hline $\mathrm{CV}(\%)$ & 9.8 & 10.1 & 5.7 & 6.2 & 14.3 & 12.2 & 15.3 & 16.2 & 3.4 & 3.8 & 4.1 & 4.2 \\
\hline
\end{tabular}

y Within columns, means followed by the same letter are not significantly different at $P=0.05$; LSD $=$ least significant difference; CV $(\%)=$ coefficient of variation; $\mathrm{R}_{830}=$ reflectance at $830 \mathrm{~nm}$; and DVI = difference vegetative index. Higher values of $\mathrm{R}_{830}$ and the DVI indicate less foliar disease.

${ }^{\mathrm{z}}$ Pyraclostrobin, low $=$ pyraclostrobin at $75 \mathrm{~g}$ a.i./ha + boscalid at $252 \mathrm{~g}$ a.i./ha and Pyraclostrobin, high $=$ pyraclostrobin at $150 \mathrm{~g}$ a.i.//ha + boscalid at 504 g a.i./ha.

Table 5. Effect of fungicides on visually and remotely assessed disease intensity in field trial $4^{\mathrm{y}}$

\begin{tabular}{|c|c|c|c|c|c|c|c|c|c|c|}
\hline \multirow[b]{2}{*}{ Treatments $^{\mathrm{z}}$} & \multicolumn{2}{|c|}{$\begin{array}{l}\text { Stem height } \\
(\mathrm{cm})\end{array}$} & \multicolumn{2}{|c|}{$\begin{array}{c}\text { Defoliation severity } \\
(\%)\end{array}$} & \multicolumn{2}{|c|}{$\begin{array}{l}\text { Flowers } \\
\text { per stem }\end{array}$} & \multicolumn{2}{|c|}{$\begin{array}{c}\text { Stems with ray blight } \\
(\%)\end{array}$} & \multirow{2}{*}{$\frac{\mathbf{R}_{\mathbf{8 3 0}}}{18 \text { Nov }}$} & \multirow{2}{*}{$\frac{\text { DVI }}{18 \mathrm{Nov}}$} \\
\hline & 24 Oct & 20 Nov & 24 Oct & 20 Nov & 24 Oct & 20 Nov & 24 Oct & 20 Nov & & \\
\hline Chlorothalonil & $38.9 \mathrm{~b}$ & $64.9 \mathrm{~b}$ & $39.3 \mathrm{a}$ & $47.8 \mathrm{~b}$ & $1.8 \mathrm{~b}$ & 5.7 & $22.3 \mathrm{a}$ & $14.5 \mathrm{ab}$ & $34.35 \mathrm{~b}$ & $29.05 \mathrm{~b}$ \\
\hline Pyraclostrobin + boscalid & $52.5 \mathrm{a}$ & $70.1 \mathrm{a}$ & $9.8 \mathrm{~b}$ & $31.8 \mathrm{c}$ & $2.7 \mathrm{a}$ & 6.4 & $0 \mathrm{~b}$ & $2 \mathrm{~b}$ & $39.45 \mathrm{a}$ & $34.04 \mathrm{a}$ \\
\hline Pyraclostrobin, high & $47.9 \mathrm{a}$ & $67.7 \mathrm{ab}$ & $22.2 \mathrm{~b}$ & $35.3 \mathrm{c}$ & $2.7 \mathrm{a}$ & 6.6 & $2 b$ & $1 \mathrm{~b}$ & $37.27 \mathrm{a}$ & $31.92 \mathrm{a}$ \\
\hline Pyraclostrobin, low & $47.4 \mathrm{a}$ & $65.5 \mathrm{ab}$ & $15.3 \mathrm{~b}$ & $36.5 \mathrm{c}$ & $2.5 \mathrm{ab}$ & 4.9 & $2 \mathrm{~b}$ & $14.8 \mathrm{ab}$ & $37.38 \mathrm{a}$ & $32.06 \mathrm{a}$ \\
\hline Boscalid, high & $51.7 \mathrm{a}$ & $67.8 \mathrm{ab}$ & $12.6 \mathrm{~b}$ & $34.9 \mathrm{c}$ & $2.6 \mathrm{a}$ & 5.8 & $0 \mathrm{~b}$ & $4.7 \mathrm{~b}$ & $38.36 \mathrm{a}$ & $33 \mathrm{a}$ \\
\hline Boscalid, low & $51.2 \mathrm{a}$ & $65.3 \mathrm{ab}$ & $9.5 \mathrm{~b}$ & $38.1 \mathrm{bc}$ & $2.6 \mathrm{a}$ & 5.1 & $0 \mathrm{~b}$ & $2.3 \mathrm{~b}$ & $38.09 \mathrm{a}$ & $32.43 \mathrm{a}$ \\
\hline Nontreated & $36.8 \mathrm{~b}$ & $58.8 \mathrm{c}$ & $46.6 \mathrm{a}$ & $59 \mathrm{a}$ & $1.9 \mathrm{~b}$ & 6 & $35.2 \mathrm{a}$ & $28.7 \mathrm{a}$ & $31.11 \mathrm{c}$ & $25.74 \mathrm{c}$ \\
\hline $\operatorname{LSD}(P<0.005)$ & 5.6 & 4.8 & 13.5 & 11.1 & 0.6 & ns & 6.4 & 15.3 & 2.58 & 2.53 \\
\hline $\mathrm{CV}(\%)$ & 11.8 & 7 & 47.2 & 23.8 & 24.5 & 24.8 & 87 & 106.4 & 6.9 & 8 \\
\hline
\end{tabular}

y Within columns, means followed by the same letter are not significantly different at $P=0.05$; ns $=$ not significant at $P=0.05$; LSD $=$ least significant difference; $\mathrm{CV}(\%)=$ coefficient of variation; $\mathrm{R}_{830}=$ reflectance at $830 \mathrm{~nm}$; and DVI = difference vegetative index. Higher values of $\mathrm{R}_{830}$ and the DVI indicate less foliar disease.

${ }^{\mathrm{z}}$ Pyraclostrobin, high $=$ pyraclostrobin at $250 \mathrm{~g}$ a.i./ha + chlorothalonil; Pyraclostrobin, low $=$ pyraclostrobin at $125 \mathrm{~g}$ a.i./ha + chlorothalonil; Boscalid, high $=$ boscalid at $500 \mathrm{~g}$ a.i./ha + chlorothalonil; and Boscalid, low = boscalid at $250 \mathrm{~g}$ a.i./ha + chlorothalonil.

Table 6. Effect of fungicides on visually and remotely assessed disease intensity in field trial $5^{\mathrm{y}}$

\begin{tabular}{|c|c|c|c|c|c|c|c|c|c|c|}
\hline \multirow[b]{2}{*}{ Treatments $^{\mathrm{z}}$} & \multicolumn{2}{|c|}{$\begin{array}{l}\text { Stem height } \\
(\mathrm{cm})\end{array}$} & \multicolumn{2}{|c|}{$\begin{array}{c}\text { Defoliation severity } \\
(\%)\end{array}$} & \multicolumn{2}{|c|}{$\begin{array}{l}\text { Flowers } \\
\text { per stem }\end{array}$} & \multicolumn{2}{|c|}{$\begin{array}{c}\text { Stems with ray blight } \\
(\%)\end{array}$} & \multirow{2}{*}{$\begin{array}{c}\mathbf{R}_{\mathbf{8 3 0}} \\
24 \text { Nov }\end{array}$} & \multirow{2}{*}{$\frac{\text { DVI }}{24 \text { Nov }}$} \\
\hline & 24 Oct & 20 Nov & 24 Oct & $20 \mathrm{Nov}$ & 24 Oct & $20 \mathrm{Nov}$ & 24 Oct & 20 Nov & & \\
\hline Chlorothalonil & $51.7 \mathrm{c}$ & $67.1 \mathrm{a}$ & $29.9 \mathrm{bc}$ & $40.8 \mathrm{~b}$ & 4.8 & 6 & $5.7 \mathrm{~b}$ & $7.8 \mathrm{~b}$ & $36.97 \mathrm{c}$ & $26.19 \mathrm{c}$ \\
\hline Pyraclostrobin + boscalid & $58.4 \mathrm{a}$ & $71.5 \mathrm{a}$ & $20.8 \mathrm{~d}$ & $40.5 \mathrm{~b}$ & 5.6 & 6.1 & $0 \mathrm{~b}$ & $0 \mathrm{~b}$ & $41.61 \mathrm{a}$ & $30.1 \mathrm{a}$ \\
\hline Pyraclostrobin, high & $57 \mathrm{ab}$ & $70 \mathrm{a}$ & $23 \mathrm{~cd}$ & $39.5 \mathrm{~b}$ & 5.1 & 5.2 & $0 \mathrm{~b}$ & $3.9 \mathrm{~b}$ & $40.19 \mathrm{ab}$ & $29.7 \mathrm{ab}$ \\
\hline Pyraclostrobin, low & $54.7 \mathrm{bc}$ & $71 \mathrm{a}$ & $24.8 \mathrm{bcd}$ & $39.9 \mathrm{~b}$ & 5.1 & 6.2 & $0.8 \mathrm{~b}$ & $0 \mathrm{~b}$ & $39.56 \mathrm{~b}$ & $28.73 \mathrm{ab}$ \\
\hline Boscalid, high & $56.8 \mathrm{ab}$ & $71.5 \mathrm{a}$ & $22.8 \mathrm{~cd}$ & $33.3 \mathrm{~b}$ & 4.5 & 6.3 & $0.4 \mathrm{~b}$ & $0 \mathrm{~b}$ & $39.5 \mathrm{~b}$ & $28.11 \mathrm{~b}$ \\
\hline Boscalid, low & $55.5 \mathrm{ab}$ & $69.1 \mathrm{a}$ & $23.8 \mathrm{~cd}$ & $41.6 \mathrm{~b}$ & 4.8 & 5.5 & $1 \mathrm{~b}$ & $0 \mathrm{~b}$ & $39.09 \mathrm{~b}$ & $28.27 \mathrm{ab}$ \\
\hline Nontreated & $45.5 \mathrm{~d}$ & $60.1 \mathrm{~b}$ & $45.7 \mathrm{a}$ & $56.5 \mathrm{a}$ & 4.1 & 5.4 & $18.1 \mathrm{a}$ & $19.8 \mathrm{a}$ & $36.83 \mathrm{c}$ & $25.69 \mathrm{c}$ \\
\hline $\operatorname{LSD}(P<0.001)$ & 3.5 & 4.9 & 8.5 & 12.9 & ns & ns & 9.9 & 10 & 1.89 & 1.83 \\
\hline $\mathrm{CV}(\%)$ & 6.2 & 7 & 25.1 & 27.3 & 19.5 & 17.9 & 140.7 & 124.7 & 4.6 & 6.3 \\
\hline
\end{tabular}

y Within columns, means followed by the same letter are not significantly different at $P=0.05$; ns $=$ not significant at $P=0.05$; LSD $=$ least significant difference; $\mathrm{CV}(\%)=$ coefficient of variation; $\mathrm{R}_{830}=$ reflectance at $830 \mathrm{~nm}$; DVI $=$ difference vegetative index. Higher values of $\mathrm{R}_{830}$ and the DVI indicate less foliar disease.

${ }^{\mathrm{z}}$ Pyraclostrobin, high $=$ pyraclostrobin at $250 \mathrm{~g}$ a.i./ha + chlorothalonil; Pyraclostrobin, low $=$ pyraclostrobin at $125 \mathrm{~g}$ a.i./ha + chlorothalonil; Boscalid, high = boscalid at $500 \mathrm{~g}$ a.i./ha + chlorothalonil; and Boscalid, low = boscalid at $250 \mathrm{~g}$ a.i./ha + chlorothalonil. 
2, $P=0.184)$ but led to increases in pyrethrin yield (Table 7). In trial 1 , the dry weight of flowers was $120 \%$ higher in plots receiving pyraclostrobin + boscalid compared with nontreated plots, which was higher than all other fungicides, which were not different from each other. Pyrethrin content within the flowers was significantly higher in plots receiving fungicides, except pyrimethanil + chlorothalonil, compared with nontreated plots, suggesting pyrimethanil may have had a deleterious effect on pyrethrin content within the flowers at this location (Table 7). Similar increases in pyrethrin yield from fungicides also were found in trial 2. Increases in the dry weight of flowers were obtained from all fungicides except epoxiconazole compared with nontreated plots. However, at this location, the average dry weight of individual flowers and pyrethrin content within the flowers was similar among fungicides. Total pyrethrin yield in plots receiving pyraclostrobin + boscalid also was superior than all other fungicides tested and 26\% higher than in nontreated plots (Table 7).

Trial 3. In trial 3, plant density, disease intensity, stem height, and flowers per stem were similar among fungicide treatments prior to the application of fungicides $(0.486<P<0.971)$. On both assessments, increases in stem height from fungicide application ranged from 32 to $71 \%$ compared with nontreated plots. Similarly, the number of flowers per stem was increased

Table 7. Effect of fungicides on relative dry weight of flowers, pyrethrin content within the flowers, and pyrethrin yield (compared to nontreated plots) in the replicated field trials ${ }^{\mathrm{z}}$

\begin{tabular}{|c|c|c|c|c|c|}
\hline Treatments & $\begin{array}{c}\text { Increase in dry } \\
\text { weight of flowers } \\
(\%)\end{array}$ & $\begin{array}{c}\text { Increase in } \\
\text { pyrethrin content } \\
\text { within the flowers } \\
(\%)\end{array}$ & $\begin{array}{c}\text { Increase in } \\
\text { pyrethrin yield } \\
(\%)\end{array}$ & $\begin{array}{c}\text { Increase in } \\
\text { dry weight of one } \\
\text { flower }(\%)\end{array}$ & $\begin{array}{l}\text { Incidence of } \\
\text { flowers with } \\
\text { ray blight }(\%)\end{array}$ \\
\hline \multicolumn{6}{|l|}{ Trial 1} \\
\hline Azoxystrobin & $63 \mathrm{~b}$ & $8 \mathrm{a}$ & $86 \mathrm{~b}$ & $-20 \mathrm{bc}$ & $8 \mathrm{bc}$ \\
\hline Pyraclostrobin + boscalid & $120 \mathrm{a}$ & $6 \mathrm{ab}$ & $132 \mathrm{a}$ & $-31 \mathrm{c}$ & $1 \mathrm{c}$ \\
\hline Kresoxim-methyl & $50 \mathrm{~b}$ & $5 \mathrm{ab}$ & $55 \mathrm{bc}$ & $-22 \mathrm{c}$ & $12 \mathrm{bc}$ \\
\hline Chlorothalonil & $35 \mathrm{~b}$ & $5 \mathrm{ab}$ & $39 \mathrm{c}$ & $-24 c$ & $13 \mathrm{~b}$ \\
\hline Epoxiconazole & $39 \mathrm{~b}$ & $6 a b$ & $46 \mathrm{c}$ & ns & $18 \mathrm{~b}$ \\
\hline Pyrimethanil + chlorothalonil & $45 \mathrm{~b}$ & $4 \mathrm{bc}$ & $48 \mathrm{c}$ & ns & $14 \mathrm{bc}$ \\
\hline Nontreated & & & & & $31 \mathrm{a}$ \\
\hline$P$ & $<0.001$ & 0.004 & $<0.001$ & 0.01 & $<0.001$ \\
\hline $\mathrm{CV}(\%)$ & 5.2 & 7.4 & 2.3 & 7.4 & 4.9 \\
\hline \multicolumn{6}{|l|}{ Trial 2} \\
\hline Azoxystrobin & $21 \mathrm{ab}$ & ns & $10 \mathrm{bc}$ & $\ldots$ & $5 \mathrm{~b}$ \\
\hline Pyraclostrobin + boscalid & $28 \mathrm{a}$ & ns & $26 \mathrm{a}$ & $\ldots$ & $1 \mathrm{~b}$ \\
\hline Kresoxim-methyl & $16 \mathrm{bc}$ & ns & $13 \mathrm{~b}$ & $\ldots$ & $3 \mathrm{~b}$ \\
\hline Chlorothalonil & $12 \mathrm{c}$ & $\mathrm{ns}$ & $9 \mathrm{bc}$ & $\ldots$ & $5 \mathrm{~b}$ \\
\hline Epoxiconazole & ns & $\mathrm{ns}$ & ns & $\ldots$ & $7 \mathrm{~b}$ \\
\hline Pyrimethanil + chlorothalonil & $20 \mathrm{~b}$ & ns & $6 \mathrm{c}$ & $\ldots$ & $8 \mathrm{~b}$ \\
\hline Nontreated & $\ldots$ & $\ldots$ & $\ldots$ & $\ldots$ & $22 \mathrm{a}$ \\
\hline$P$ & $<0.001$ & $0.415(\mathrm{~ns})$ & 0.002 & $\ldots$ & 0.01 \\
\hline $\mathrm{CV}(\%)$ & 2.3 & 34.5 & 5.2 & $\ldots$ & 6.2 \\
\hline Trial 3 & & & & $\ldots$ & \\
\hline Azoxystrobin & $131 \mathrm{~b}$ & $11 \mathrm{a}$ & $165 a b$ & $\ldots$ & 2 \\
\hline Pyraclostrobin & $133 \mathrm{~b}$ & $11 \mathrm{a}$ & $163 \mathrm{~b}$ & $\ldots$ & 3 \\
\hline Pyraclostrobin & & & & $\ldots$ & \\
\hline$(75 \mathrm{~g}$ a.i./ha $)+$ & & & & $\ldots$ & \\
\hline boscalid (252 g a.i./ha) & $142 \mathrm{ab}$ & $10 \mathrm{a}$ & $165 \mathrm{~b}$ & $\ldots$ & 2 \\
\hline Pyraclostrobin & & & & $\ldots$ & \\
\hline$(150 \mathrm{~g}$ a.i./ha $)+$ & & & & $\ldots$ & \\
\hline boscalid (504 g a.i./ha) & $166 \mathrm{ab}$ & $12 \mathrm{a}$ & $194 \mathrm{a}$ & $\ldots$ & 1 \\
\hline Boscalid & $154 \mathrm{ab}$ & $9 \mathrm{a}$ & $164 \mathrm{~b}$ & $\ldots$ & 1 \\
\hline Difenoconazole & $83 \mathrm{c}$ & $14 \mathrm{a}$ & $123 \mathrm{c}$ & $\ldots$ & 4 \\
\hline Nontreated & $\ldots$ & $\ldots$ & $\ldots$ & $\ldots$ & 6 \\
\hline$P$ & $<0.001$ & $<0.001$ & $<0.001$ & $\ldots$ & $0.523(\mathrm{~ns})$ \\
\hline $\mathrm{CV}(\%)$ & 5.7 & 2.4 & 16.3 & $\ldots$ & 16.5 \\
\hline \multicolumn{6}{|l|}{ Trial 4} \\
\hline Chlorothalonil & $10 \mathrm{~b}$ & ns & ns & $\ldots$ & 7 \\
\hline Pyraclostrobin + boscalid & $52 \mathrm{a}$ & $\mathrm{ns}$ & $56 \mathrm{a}$ & $\ldots$ & 4 \\
\hline Pyraclostrobin $(250 \mathrm{~g}$ a.i./ha $)+$ chlorothalonil & 37 a & ns & $34 \mathrm{a}$ & $\ldots$ & 6 \\
\hline Pyraclostrobin ( $125 \mathrm{~g}$ a.i./ha $)+$ chlorothalonil & $48 \mathrm{a}$ & $-6 b$ & $39 \mathrm{a}$ & $\ldots$ & 8 \\
\hline Boscalid (500 g a.i./ha) + chlorothalonil & $45 \mathrm{a}$ & $-5 b$ & $36 \mathrm{a}$ & $\ldots$ & 5 \\
\hline Boscalid (250 g a.i./ha) + chlorothalonil & $42 \mathrm{a}$ & $\mathrm{ns}$ & $39 \mathrm{a}$ & $\ldots$ & 10 \\
\hline Nontreated & - & $\ldots$ & $\ldots$ & $\ldots$ & 9 \\
\hline$P$ & $<0.001$ & 0.044 & $<0.001$ & $\ldots$ & $0.379(\mathrm{~ns})$ \\
\hline $\mathrm{CV}(\%)$ & 18.5 & 5.1 & 18.9 & $\ldots$ & 121.5 \\
\hline Trial 5 & & & & $\ldots$ & \\
\hline Chlorothalonil & $40 \mathrm{ab}$ & $-7 \mathrm{c}$ & $30 \mathrm{bc}$ & $\ldots$ & 4 \\
\hline Pyraclostrobin + boscalid & $49 \mathrm{ab}$ & $-4 a b c$ & $44 \mathrm{ab}$ & $\ldots$ & 0 \\
\hline Pyraclostrobin $(250 \mathrm{~g}$ a.i./ha $)+$ chlorothalonil & $52 \mathrm{ab}$ & $-3 a b$ & $49 \mathrm{a}$ & $\ldots$ & 0 \\
\hline Pyraclostrobin $(125 \mathrm{~g}$ a.i./ha $)+$ chlorothalonil & $52 \mathrm{ab}$ & $-5 \mathrm{bc}$ & $46 \mathrm{ab}$ & $\ldots$ & 2 \\
\hline Boscalid (500 g a.i./ha) + chlorothalonil & $53 \mathrm{a}$ & $-9 a b c$ & $48 \mathrm{ab}$ & $\ldots$ & 5 \\
\hline Boscalid (250 g a.i./ha) + chlorothalonil & $49 \mathrm{ab}$ & $-4 a b c$ & $44 \mathrm{ab}$ & $\ldots$ & 4 \\
\hline Nontreated & & & $\ldots$ & $\ldots$ & 3 \\
\hline$P$ & $<0.001$ & $<0.001$ & $<0.001$ & $\cdots$ & $0.363(\mathrm{~ns})$ \\
\hline $\mathrm{CV}(\%)$ & 10.6 & 3.6 & 11.5 & $\ldots$ & 64.5 \\
\hline
\end{tabular}

${ }^{\mathrm{z}}$ Within columns, means followed by the same letter are not significantly different at $P=0.05$; ns $=$ not significant; LSD $=$ least significant difference; CV $(\%)=$ coefficient of variation. 
over nontreated plots from 18 to $53 \%$. Canopy reflectance at $830 \mathrm{~nm}$ and measured by the DVI also were similar among fungicide treatments, with the exception of difenoconazole. On both assessments and in common with the visual assessment measures, canopy reflectance at 830 $\mathrm{nm}$ and the DVI were highest in plots receiving pyraclostrobin + boscalid regardless of rate, ranging between 74 and $105 \%$ (Table 4).

Flower maturity was similar between fungicides $(P=0.885)$. The dry weight of flowers, pyrethrin content within the flowers, and total pyrethrin yield were increased from the application of all fungicides; however, difenoconazole produced the smallest increases compared with nontreated plots (Table 7). Increases in the dry weight of flowers from fungicide application, with the exception of plots receiving boscalid, were attributed to larger individual flowers. The highest rate of pyraclostrobin + boscalid tested increased total pyrethrin yield by $29 \%$ compared with the lower rate, and 30 to $31 \%$ compared with pyraclostrobin and boscalid when applied individually (Table 7).

Trials 4 and 5. In both trials, plant density and disease severity were similar among fungicide treatments $(0.432<P<$ 0.652 ) prior to application. On 24 October and 20 November, increases in stem height compared with nontreated plots were apparent in all plots receiving fungicides, with the exception of those receiving chlorothalonil only on 24 October, and ranged from 11 to $43 \%$ (Tables 5 and 6). All fungicides also were effective at reducing defoliation severity compared with nontreated plots on 20 November. Flowers per stem in plots receiving fungicides, except chlorothalonil, were at least $37 \%$ higher than in nontreated plots (Tables 5 and 6).

Trends in reductions in defoliation severity, the incidence of stems with ray blight, and canopy reflectance similar to those in trial 4 also were found in trial 5 . On 24 October, stems were taller in all fungicide-treated plots compared with nontreated plots, with the exception of chlorothalonil. However, on 20 November, stems in all fungicide-treated plots were taller than in nontreated plots, ranging from $11 \%$ of plots receiving chlorothalonil to $19 \%$ in those also receiving boscalid at $500 \mathrm{~g}$ a.i./ha (Tables 5 and 6).

Flower maturity was similar between treatments $(0.306<P<0.522)$. In both trials, the dry weight of flowers and pyrethrin yield were increased compared with nontreated plots from pyraclostrobin or boscalid regardless of rate (Table 7). Furthermore, all fungicides, with the exception of chlorothalonil in trial 4 , increased pyrethrin yield and the dry weight of flowers compared with nontreated plots. The dry weight of one flower was similar among treatments in both trials $(0.493<P$
$<0.535)$, suggesting that the increase in dry weight of flowers and pyrethrin yield from fungicides was due to the production of more flowers per unit area. In both trials, the incidence of flowers with ray blight was similar among treatments $(0.363<P<0.379$; Table 7$)$.

Single-plot field assessments. Plant density and disease severity on leaves was similar among treatments across all fields $(0.422<P<0.565)$ prior to the application of fungicides. Defoliation severity and flowers per stem were also similar $(0.188$ $<P<0.753)$ among treatments in September, whereas stems in plots treated with pyraclostrobin + boscalid were $5 \%$ taller than those in nontreated plots. In October, application of pyraclostrobin + boscalid and the commercially recommended fungicide protocol reduced defoliation severity by 90 and $78 \%$, respectively, compared with nontreated plots. Furthermore, in October and November, defoliation severity was reduced in plots receiving pyraclostrobin + boscalid compared with plots receiving the commercially recommended protocol, by an average of $37 \%$ (Table 8 ). Stem height in both October and November followed a similar pattern, with stems in plots receiving pyraclostrobin + boscalid being 13 and $8 \%$ taller, respectively, than plots receiving the commercially recommended protocol (Table 8). Flower maturity and pyrethrin content within flowers were similar among treatments $(0.578<P$ $<0.752$ ). Relative to the nontreated plots, pyrethrin yield was increased by 134 and $60 \%$ by pyraclostrobin + boscalid and the commercially recommended protocol, respectively. Moreover, application of pyraclostrobin + boscalid increased pyrethrin yield by $20 \%$ compared with the commercially recommended protocol.

\section{DISCUSSION}

These trials quantified the efficacy of a range of fungicides as candidates for incorporation into the commercial recommendations for ray blight disease management in Tasmanian pyrethrum fields. Results from in vitro and field trials over all three seasons clearly demonstrated benefits from mixtures of pyraclostrobin + boscalid. These fungicides reduced foliar disease intensity, as measured by defoliation severity and the incidence of stems and flowers with blight, and increased stem height and the number of flowers produced on each stem in October and November. Differences in canopy reflectance at $830 \mathrm{~nm}$ and the DVI also were noted and were consistent with other measurements. This is consistent with previous studies which have demonstrated that benefits from fungicide application result from increasing the amount of healthy tissue or the green leaf area and, hence, the ability of the plant to produce stems and flowers during this rapid growth phase $(31,34)$. Fungicides had no effect on flower maturity, suggesting that the differences in pyrethrin content were not related to changing flower maturity (25). The response from fungicides on the components of yield differed according to season and location. For example, in trial 1, applications of pyraclostrobin + boscalid increased pyrethrin content within the flowers and the dry weight of flowers, resulting in increased pyrethrin yield. There also was a reduction in dry weight of individual flowers, which suggested that more flowers were produced and less were diseased; however, presumably because of competition, these flowers were smaller. Conversely, in trial 2 in the same season, pyraclostrobin + boscalid increased pyrethrin

Table 8. Impact of pyraclostrobin + boscalid and the commercial recommended fungicide protocol on stem height, defoliation severity, number of flowers produced on each stem, and incidence of stems with ray blight in the single-plot field assessments in eight pyrethrum fields across northern Tasmania in $2005^{\mathrm{z}}$

\begin{tabular}{|c|c|c|c|c|}
\hline Treatment & $\begin{array}{l}\text { Stem height } \\
\text { (cm) }\end{array}$ & $\begin{array}{c}\text { Defoliation } \\
\text { severity } \\
(\%)\end{array}$ & $\begin{array}{l}\text { Flowers } \\
\text { per stem }\end{array}$ & $\begin{array}{c}\text { Stems with } \\
\text { ray blight } \\
(\%)\end{array}$ \\
\hline \multicolumn{5}{|l|}{ September } \\
\hline Pyraclostrobin + boscalid & $20.8 \mathrm{a}$ & 11.0 & 1.3 & 0 \\
\hline Commercial recommendations & $20.3 \mathrm{ab}$ & 11.8 & 1.3 & 0 \\
\hline Nontreated & $19.9 \mathrm{~b}$ & 12.2 & 1.2 & 0 \\
\hline $\operatorname{LSD}(P)$ & $0.7(0.022)$ & ns & $\mathrm{ns}$ & $\ldots$ \\
\hline $\mathrm{CV}(\%)$ & 5.6 & 18.5 & 10.6 & $\ldots$ \\
\hline \multicolumn{5}{|l|}{ October } \\
\hline Pyraclostrobin + boscalid & $41.4 \mathrm{a}$ & $3.9 \mathrm{c}$ & $2.0 \mathrm{a}$ & $0 \mathrm{c}$ \\
\hline Commercial recommendations & $36.5 \mathrm{~b}$ & $8.1 \mathrm{~b}$ & $1.9 \mathrm{a}$ & $1.9 \mathrm{~b}$ \\
\hline Nontreated & $27.5 \mathrm{c}$ & $35.9 \mathrm{a}$ & $1.4 \mathrm{~b}$ & $14.9 \mathrm{a}$ \\
\hline $\operatorname{LSD}(P)$ & $1.7(<0.001)$ & $1.2(<0.001)$ & $0.2(<0.001)$ & $1.1(<0.001)$ \\
\hline $\mathrm{CV}(\%)$ & 8.2 & 6.8 & 14 & 14.2 \\
\hline \multicolumn{5}{|l|}{ November } \\
\hline Pyraclostrobin + boscalid & $74.2 \mathrm{a}$ & $33.9 \mathrm{c}$ & $4.4 \mathrm{a}$ & $1.0 \mathrm{c}$ \\
\hline Commercial recommendations & $68.9 \mathrm{~b}$ & $42.9 \mathrm{~b}$ & $4.5 \mathrm{a}$ & $11.7 \mathrm{~b}$ \\
\hline Nontreated & $54.6 \mathrm{c}$ & $64.7 \mathrm{a}$ & $3.8 \mathrm{~b}$ & $39.7 \mathrm{a}$ \\
\hline $\operatorname{LSD}(P)$ & $2.2(<0.001)$ & $3.5(<0.001)$ & $0.4(0.003)$ & $2.4(<0.001)$ \\
\hline $\mathrm{CV}(\%)$ & 5.6 & 12.8 & 17.2 & 10.2 \\
\hline
\end{tabular}

${ }^{\mathrm{z}}$ Within columns, means followed by the same letter are not significantly different at $P=0.05$; ns $=$ not significant at $P=0.05 ; \mathrm{LSD}=$ least significant difference; $\mathrm{CV}(\%)=$ coefficient of variation. 
yield by increasing the dry weight of flowers; however, dry weight of individual flowers and pyrethrin content were similar, suggesting that yield increases were due to the production of a greater number of healthy flowers. In trial 3, yield increases from fungicides were due to the production of higher numbers of larger flowers. However, when boscalid was applied alone, individual flower weights were lower than all other fungicides and not different from those which did not receive any fungicides. Moreover, in trials 4 and 5, yield increases were due to the production of higher numbers of flowers, while the weight of individual flowers was similar. The effect of fungicides on pyrethrin content within the flowers was not consistent across locations.

These studies have demonstrated that the two components of Pristine, pyraclostrobin and boscalid, have similar efficacy in reducing disease intensity and increasing pyrethrin yield. Considering that pyraclostrobin is in the same strobilurin group as azoxystrobin, which is already in the current measures for control, we recommend that either of these could be used but that the use of strobilurins still be restricted to two applications per year. This is due to concerns over the development of resistance to strobilurins. These fungicides have a specific single-site mode of action within the cytochrome $b$ gene (28). The incorporation of boscalid into the commercial recommendations will provide further flexibility to growers in the form of an additional fungicide in a different resistance group and allow difenoconazole to be removed from the recommendations for ray blight disease management due to reduced sensitivity (16). Negative crosssensitivity associated with the substitution of phenylalanine with leucine at position 129 (F129L mutation) of reduced sensitivity to strobilurin fungicides and boscalid have been reported in $A$. solani, which is associated with an approximately 10-fold loss of sensitivity under in vitro conditions $(29,30)$. To further slow resistance development for both the strobilurins and boscalid, we recommend following strategies similar to those outlined by Pasche et al. (29). These include tank mixing these products with fungicides with other modes of action, using fungicides in a preventative program, and alternating with products of different groups. A minor use permit (PER8820) was successfully obtained from the Australian Pesticides and Veterinary Authority for the use of boscalid in Tasmanian pyrethrum fields in 2006 at the higher rate of $500 \mathrm{~g} / \mathrm{kg}$ a.i./ha. Further research will focus on reducing the reliance of the management strategies for ray blight disease on fungicides, including the identification of resistant cultivars, deployment of cultivar mixtures to reduce disease development $(9,42)$, and manipulating agronomic fac- tors which may influence disease intensity.

\section{ACKNOWLEDGMENTS}

This project was funded by Botanical Resources Australia Pty. Ltd. and the Australian Research Council Linkage program (LP0211065 and LP0560562). We thank the pyrethrum growers who allowed access to their crops for field trials and C. Palmer and T. O'Malley for technical assistance.

\section{LITERATURE CITED}

1. Avenot, H. F., and Michailides, T. J. 2007. Resistance to boscalid fungicide in Alternaria alternata isolates from pistachio in California. Plant Dis. 91:1345-1350.

2. Baker, K. F., Dimock, A. W., and Davis, L. H. 1949. Life history and control of the Ascochyta ray blight of chrysanthemum. Phytopathology 39:789-805.

3. Baker, K. F., Dimock, A. W., and Davis, L. H. 1961. Cause and prevention of the rapid spread of the Ascochyta disease of chrysanthemum. Phytopathology 51:96-101.

4. Baret, F., and Guyot, G. 1991. Potentials and limits of vegetation indices for LAI and APAR assessment. Remote Sens. Environ. 35:161173.

5. Broge, N. H., and Leblanc, E. 2000. Comparing prediction power and stability of broadband and hyperspectral vegetation indices for estimation of green leaf area index and canopy chlorophyll density. Remote Sens. Environ. 76:156-172.

6. Buchenauer, H. 1987. Mechanisms of action of triazolyl fungicides and related compounds. Pages 205-232 in: Modern Selective Fungicides-Properties, Applications and Mechanisms of Action. H. Lyr, ed. John Wiley and Sons, New York.

7. Casida, J. E., and Quistad, G. B. 1995. Pyrethrum Flowers: Production, Chemistry, Toxicology and Uses. Oxford University Press, New York.

8. Fox, R. T. V. 1998. Chrysanthemum ray blight. Mycologist 12:135-136.

9. Garrett, K. A., and Mundt, C. C. 1999. Epidemiology in mixed host populations. Phytopathology 89:984-990.

10. Gisi, U., Chin, K. M., Knapova, G., Farber, R. K., Mohr, U., Parisi, S., Sierotzki, H., and Steinfeld, U. 2000. Recent developments in elucidating modes of action of resistance to phenylamide, DMI, and strobilurin fungicides. Crop Prot. 19:836-872.

11. Guan, J., and Nutter, F. W., Jr. 2001. Factors affecting the quality and quantity of sunlight reflected from alfalfa canopies. Plant Dis. 85:865-874.

12. Guan, J., and Nutter, F. W., Jr. 2004. Comparison of single-point alfalfa yield models based on visual disease intensity and remote sensing assessments. Can. J. Plant Pathol. 26:314-324.

13. Hanson, B. K., and Lamey, H. A. 2001. Evaluation of foliar fungicides on canola for Sclerotinia stem rot, 2000. Fungic. Nematicide Tests 56:FC1.

14. Horwitz, W. 1980. Official Methods of the Association of Official Analytical Chemists (AOAC). Analysis of Pyrethrum Extract, AOAC 9th ed. Fairfield American Corporation Pyrethrins Mercury Reduction Method, AOAC, 9th ed. Washington, DC.

15. Ishii, H., Fraaije, B. A., Sugiyama, T., Noguchi, K., Nishimura, K., Takeda, T., Ameno, T., and Hollomon, D. W. 2001. Occurrence and molecular characterization of strobilurin resistance in cucumber powdery mildew and downy mildew. Phytopathology 91:1166-1171.

16. Jones, S., Pethybridge S. J., Hay, F. S., Groom, T., and Wilson, C. R. 2007. Baseline sensitivity of Australian Phoma ligulicola isolates from pyrethrum to azoxystrobin and difenoconazole.
J. Phytopathol. 155:377-380.

17. Koike, S. T., Subbarao, K. V., Verkley, G. J. M., Fogle, D., and O'Neill, T. M. 2006. Phoma basal rot of romaine lettuce in California caused by Phoma exigua: occurrence, characterization, and control. Plant Dis. 90:12681275.

18. Köller, W. W. 1996. Recent developments in DMI resistance. Pages 301-311 in: Modern Antifungal Compounds. Intercept Ltd., Andover, UK.

19. Köller, W. W., Parker, D. M., Turechek, W. W. Avila-Adame, C., and Cronshaw, K. 2004. A two-phase resistance response of Venturia inaequalis populations to the $\mathrm{QoI}$ fungicides kresoxim-methyl and trifloxystrobin. Plant Dis. 88:537-544.

20. Kuhn, P. J. 1984. Mode of action of carboxamides. Symp. Ser. Br. Mycol. Soc. 9:155-183.

21. Kumar, A., Singh, S. P., and Bhakuni, R. S. 2005. Secondary metabolites of the Chrysanthemum genus and their biological activities. Curr. Sci. 89:1489-1501.

22. Leroux, P. 1986. Caractéristiques des souches d'Ustilago nuda, agent du charbon nu de l'orge résistantes à la carboxine. Agronomie 6:225-226.

23. Matheron, M. E., and Porchas, M. 2004. Activity of boscalid, fenhexamid, fluazinam, fludioxonil, and vinclozolin on growth of Sclerotinia minor and $S$. sclerotiorum and development of lettuce drop. Plant Dis. 88:665-668.

24. McEldowney, A., and Menary, R. A. 1998. Analysis of pyrethrins in pyrethrin extracts by high-performance liquid chromatography. J. Chromatogr. 447:239-243.

25. Morris, S. E., Davis, N. W., Brown, P. H., and Groom, T. 2006. Effect of drying conditions on pyrethrin content. Ind. Crops Prod. 23:9-14.

26. Newton, A. C., Hackett, C. A., Lowe, R., and Wale, S. J. 2004. Relationship between canopy reflectance and yield loss due to disease in barley. Ann. Appl. Biol. 145:96-106.

27. Nutter, F. W., Jr., and Esker, P. D. 2001. Disease assessment keys. Pages 323-326 in: Encyclopedia of Plant Pathology, Vol. 1. O. C. Maloy and T. D. Murray, eds. John Wiley \& Sons, New York.

28. Olaya, G., and Köller, W. 1999. Diversity of kresoxim-methyl sensitivities in baseline populations of Venturia inaequalis. Pestic. Sci. 55:1083-1088.

29. Pasche, J. S., Piche, L. M., and Gudmestad, N. C. 2005. Effect of the F129L mutation in $\mathrm{Al}$ ternaria solani on fungicides affecting mitochondrial respiration. Plant Dis. 89:269-278.

30. Pasche, J. S., Wharman, C. M., and Gudmestad, N. C. 2004. Shift in sensitivity of Alternaria solani to $\mathrm{Q}_{0} \mathrm{I}$ fungicides. Plant Dis. 88:181-187.

31. Pethybridge, S. J., Esker, P. D., Dixon, P., Hay, F. S, Groom, T., Wilson, C. R., and Nutter, F. W., Jr. 2007. Quantifying loss caused by ray blight disease in Tasmanian pyrethrum fields. Plant Dis. 91:1116-1121.

32. Pethybridge S. J., Esker, P. D., Hay, F. S. Wilson, C. R., and Nutter, F. W. Jr. 2005. Spatiotemporal description of epidemics caused by Phoma ligulicola in Tasmanian pyrethrum fields. Phytopathology 95:648-658.

33. Pethybridge, S. J., Hay, F. S., Esker, P. D. Groom, T., Wilson, C. R., and Nutter, F. W., Jr. 2008. Visual and radiometric assessments for yield losses caused by ray blight in pyrethrum. Crop Sci. 48:343-352.

34. Pethybridge, S. J., Hay, F. S., Esker, P. D., Wilson, C. R., and Nutter, F. W., Jr. 2007. Use of a multispectral radiometer for non-invasive assessments of foliar disease caused by ray blight in pyrethrum. Plant Dis. 91:1397-1406.

35. Pethybridge, S. J., Hay, F. S., and Groom, T. 2003. Seasonal fluctuations associated with pyrethrum foliage in Tasmania. Aust. Plant 
Pathol. 32:223-230.

36. Pethybridge, S. J., Hay, F. S., and Wilson, C. R. 2004. Pathogenicity of fungi commonly from foliar disease in Tasmanian pyrethrum crops. Aust. Plant Pathol. 33:441-444.

37. Pethybridge, S. J., Hay, F. S., Wilson, C. R., and Groom, T. 2005. Development of a fungicide-based management strategy for foliar disease caused by Phoma ligulicola in Tasmanian pyrethrum fields. Plant Dis. 89:1114-1120.

38. Pethybridge, S. J., and Wilson, C. R. 1998.
Confirmation of ray blight disease of pyrethrum in Australia. Aust. Plant Pathol. 27:4548.

39. Ryley, M. J., Kyel, N. A., and Tatnell, J. R. 2000. Evaluation of fungicides for the management of Sclerotinia blight of peanut. Aust. J. Agric. Res. 51:917-924.

40. Scheinpflug, H. 1988. History of DMI fungicides and monitoring for resistance. Pages 77-78 in: Fungicide Resistance in North America. American Phytopathological Soci- ety Press, St. Paul, MN.

41. Skinner, W., Bailey, A., Renwick, A., Keon, J., Gurr, S., and Hargreaves, J. 1998. A single amino-acid substitution in the iron sulphur protein subunit of succinate dehydrogenase determines resistance to carboxin in Mycosphaerella graminicola. Curr. Genet. 34:393-398.

42. Wolfe, M. S. 1985. The current status and prospects of multiline cultivars and variety mixtures for disease control. Phytopathology 23:251-273. 